\title{
LINKS BETWEEN THE CREATING SHARED VALUE CONCEPT AND A COMPANY'S MARKETING STRATEGY
}

\author{
Wojciech Grzegorczyk ${ }^{\bowtie}$
}

University of Lodz, Poland

\begin{abstract}
The aim of the article is to try to define the relationship between the corporate social responsibility (CSR) and the creating shared value (CSV) concepts and marketing strategy. To achieve this goal, a method of critical analysis of national and foreign literature relating to these issues was used. On this basis, conclusions were formulated defining the scope and content of these relations. They relate primarily to a company's mission, marketing research and marketing strategy. The relationship between the CSV concept and marketing strategy can be particularly seen in the evaluation and selection of new geographic markets and new buyer segments. They refer to changes in product policy - creation of products constituting common value. Relationships also relate to distribution policy, which may include the creation of local clusters and the inclusion of companies from these markets in production and distribution.
\end{abstract}

Key words: CSR, CSV, marketing strategy

JEL codes: M31

\section{INTRODUCTION}

In both the subject literature and practice we often come across the concepts of the corporate social responsibility (CSR) and the creating shared value (CSV) as well as criticism concerning particularly their practical uses. The relationship between these concepts and the marketing strategy of a company implementing or intending to implement them is very rarely discussed. The aim of this article is an attempt to define this relationship and its substance. In order to achieve this aim the author uses a critical analysis of Polish and foreign research literature concerning these issues. On the basis of this literature review the author formulates conclusions referring to the extent and substance of these relations. These conclusions relate primarily to the company's mission, its marketing research and marketing strategy.

Wojciech Grzegorczyk https://orcid.org/0000-0002-8908-6351

$\otimes_{\text {wojciech.grzegorczyk@uni.lodz.pl }}$
The presented text is the result of the first (conceptual) stage of a research project carried out at the Department of Marketing, University of Lodz. Quantitative research will be carried out in the second stage, in 2021.

\section{BASIC ASSUMPTIONS OF THE CORPORATE SOCIAL RESPONSIBILITY}

The concept of CSR assumes that the aim of modern companies is to get to know the ever-increasing social expectations of different groups of stakeholders in order to include them in the company's strategy concerning its market activities, as well as to monitor the impact of the created social-economic values on the increase in the company's market value and its competitiveness. The main objective of CSR is to ensure social sustainability. According to this assump- 
tion, it is already at the stage of building its strategy that a company voluntarily takes into account social interests, environmental protection and relations with different groups of stakeholders. Apart from a company's relations with its stakeholders they include, among others, fair market practices, the company's approach to environmental protection and its engagement in social issues and community development [Krzepicka and Tarapata 2013, Żychlewicz 2015]. A company's social responsibility with respect to stakeholders (groups interested in the company's activities) should be based on the principles of cooperation, reliable information, the will to build lasting partner relationships and mutual trust. The concept of CSR assumes that companies offer customers the highest quality products and take responsibility if they do not comply with quality and security standards. A company's activities with regard to CSR involve concern for environmental protection and the reduction of the company's negative impact on the natural environment by minimizing the harmful effects of production and consumption and improving social welfare. The ultimate goal is to achieve a balance between socio-economic growth and the preservation of natural resources [Błach et al. 2017].

In order to achieve the above-mentioned goals, companies can use different tools for CSR purposes. They involve corporate volunteering, engaging buyers and other stakeholders, social campaigns launched in cooperation with media and non-governmental organizations and various programs aimed at meeting local community expectations. They can address environmental pollution, health hazards, children and youth education, activities to prevent disabled people from deprivation, the fight against childhood malnutrition, etc. All these activities, also referred to as socially responsible investments, combine a company's internal goals (e.g. increasing sales or profits, entering new markets, etc.) with external goals related to solving social problems. As has already been mentioned, CSR activities in companies cannot be random or incidental, they should be a permanent element of the company's strategy used on a regular, not sporadic, basis. Additionally, they should also have a complex character. Implementing these activities on a permanent basis generates costs that the company has to bear. At the same time, planned and rational use of CSR tools results in positive effects such as building and improving the corporate image and implementing the company's strategic goals [Buczkowski et al. 2016].

According to Kramer and Porter, the CSR concept is implemented in stages [Witek-Crabb 2016]. The first stage involves random and sporadic activities that bring the company small economic benefit. This preliminary stage is called the stage of corporate philanthropy. The next stage is the so-called strategic philanthropy. Its activities are long-term and they are conducted in order to improve the company's competitive position. The economic effectiveness of these activities is also higher. The interest of the company, however, should be closely connected with its social and ecological activities. Therefore, these activities should evolve into the next stage of CSR which involves taking business decisions closely linked to social decisions in order to create the so-called shared value. In consequence, the company should be looking for social areas related to the company profile and make a profit and loss account of the economic and social costs related to its CSR activities [Witek-Crabb 2016]. The concept of creating shared value was presented by Porter and Kramer in Harvard Business Review in 2011 as a criticism of the CSR concept used at the time and its implementation [Porter and Kramer 2011].

\section{ASSUMPTIONS OF THE CREATING SHARED VALUE}

Porter and Kramer claimed that the CSR activities that were then used by companies had numerous drawbacks. They were often internally inconsistent and uncoordinated and corporate reports concerning them were unreliable and did not show the links between the CSR concept and corporate strategy. The concept of CSR was perceived in companies as philanthropic activities (corporate philanthropy), often caused by the pressure of the company's environment and frequently undertaken as a result of some unclear preferences. The CSR concept was treated mainly as an element of a company's costs and therefore resulted in the company's reluctance to bear them. It was not perceived as the company's chance for development. Other flaws of 
the CSR concept included the lack of effectiveness of the measures undertaken by the company and the risk that a company's CSR activities would be perceived as equivalent to public relations activities [Urbanowska-Sojkin and Weinert 2016]. As we can see, this criticism mainly referred to the practical use of CSR, and not to its essence.

The lack of consistency and internal coordination in CSR activities, unreliability of reports concerning them and the fact that there were no links between the CSR concept and the company's strategy did not result from the concept of CSR as such but, no doubt, from the activities of particular companies. The philanthropic character of CSR activities is not a drawback as long as they improve a company's competitive position and its corporate image and at the same time contribute to the improvement of the environment and public health. If CSR activities are of permanent character and, according to their assumptions, address the conditions and needs of the company's environment, they also have long-lasting and durable effects. Perceiving CSR activities as an element of a company's costs does not seem to be incorrect, either as, as a rule, every single activity carried out by a company generates costs. In practice, however, companies were, in fact, frequently not willing to undertake more advanced CSR activities because of their relatively high costs. The fact that there are no measures of the effectiveness of CSR activities, however, is a real weakness of the CSR concept; however, it does not result from the reluctance to undertake such activities, but is rather a result of the difficulty to develop indicators to measure their effectiveness. They are long-term activities and they concern building a company's image and social changes. Standards of the CSR were defined just at the turn (or in the early years) of the 21 st century. It seems that the risk of CSR activities being perceived as synonymous to public relations results from a lack of knowledge within companies and not from the CSR concept as such.

According to Porter and Kramer the solution to the drawbacks of the CSR concept is the new concept of CSV, i.e. creating shared value in social and economic areas, which, in fact, means moving to a more advanced stage of CSR. The new CSV concept emphasises the links between a company's success and social development. The CSV involves a company's activities aimed to improve its competitiveness by incorporating social activities (social causes) into its strategy. Its aim is to provide value for the company's customers by addressing, at the same time, important social and economic needs of the communities that the company operates in. The idea is to involve not only some selected stakeholders, e.g. stockholders or customers, but all the participants of the value chain. At the same time, the costs that the company bears in creating shared value should be balanced against the benefits that they bring. On the one hand, CSV activities incur costs that may lower a company's profit; on the other hand they should bring additional revenues and profits. It results from the fact that the company enters new markets and offers new products by creating shared value. The priority in the process of developing a company's strategy is to recognise problems and social issues in the company's environment. It can be said that CSV is not about undertaking charity activities but it involves developing the company's strategy in a way that takes into account the improvement of environmental well-being as well as the company's profits, and creates a new economic value.

There are three ways of implementing the CSV concept:

- First, developing new markets by recognising local community problems.

- Second, introducing new production, technological and organizational solutions in order to reduce the company's negative impact on the natural and local social environment.

- Third, enabling local clusters involved in processes of supply, production and provision of services to develop.

Thus, improving a company's competitiveness by creating shared value results from entering new markets and improving the company's image.

The CSV concept as a subsequent stage of CSR was presented in the form of a general framework and it addressed the concept of corporate social opportunities and creating the blended value. It can be concluded that CSV is an attempt to correct the flaws of the CSR concept. There is no doubt that it can be called a concept that aims to provide consistency of 
economic and social goals (sustainable development model $)^{1}$. The subject literature also presents the process of companies shifting gradually from the stage of using the CSR concept as a result of a company's environment pressure, through perceiving CSR as charity activities carried out by companies for their own satisfaction, to finally undertaking CSR activities in order to improve the company's competitiveness.

There is also a slightly different approach presented in the subject literature of implementing CSR by companies in stages. This approach mentions four or five stages of this process, the first three of which correspond to the first stage as defined by Porter and Kramer. The fourth stage is equivalent to their second one, namely to strategic charity activities and the final stage corresponds to the CSV stage [Mirvis and Goggins 2006, Visser 2012, Witek-Crabb 2016].

\section{CREATING SHARED VALUE CONCEPT AND A COMPANY'S MARKETING ACTIVITIES}

Every company preparing its marketing strategy first determines its mission and vision. A company's mission is the aim of the company's existence, the needs that it intends to satisfy and its contribution to the development of society. It is also said that a company's mission is the whole set of values that the customers and other stakeholders expect the company to provide. On the other hand, a company's vision is its projection of the future and what it is going to function like in subsequent periods of time. In other words, it is the visualisation of its future state. Thus, the CSR concept refers particularly to a company's mission because it involves, among other things, answering the question of who the company functions for, what activities it undertakes for the benefit of the community that it operates in, and what way it is going to contribute to the development of society. A marketing strategy that includes, for example, the company's marketing goals is based on the company's mission. A company's marketing goals should take into account the protection and development of the company's competitiveness, its customers' needs and, according to the CSR concept, also provide sustainable social development [Janeczek 2014]. Having established the goals, a company selects the target markets on which it is going to operate and the marketing tools that it is going to use to achieve its marketing goals.

Assuming that a company implements the CSR concept in stages, marketing used by the company that addresses this concept can be referred to as social or sustainable marketing. The use of this type of marketing also results from a change in the behaviour of customers who are increasingly interested in social and environmental issues and therefore expect ethical behaviour, reliable information and response to social needs as well as good-quality products that are ecological and safe for people's health. All this forces producers and suppliers to present an enhanced offer providing additional social and ecological benefits. Social marketing can be defined as a process of creating, communicating and providing value for customers which addresses their needs, social, economic and ethical expectations as well as the company's efforts to enhance its competitiveness [Czubała 2013]. It involves building and implementing a marketing strategy that takes into account the social consequences of decisions. In practice the most common form of marketing is so-called environmental marketing, also referred to as green, ecological or eco-marketing. Its name suggests that the activities planned by a company - and the marketing instruments it uses - are in accordance with the principles of sustainable development and are both environmentally friendly and socially responsible.

As a result, companies modify the offered products and their composition and develop new ecological products and ecological packaging. They also launch social campaigns in order to change people's attitudes and behaviours in order to make them more friendly for the natural environment [Czubała 2013]. In practice, sustainable marketing involves a wider range of activities than traditional marketing. It concerns marketing research, strategy and organisation. The data collected by a company within the marketing information system should not just concern cus-

${ }^{1}$ Some authors referred to the CSV concept as a "useful utopia" or "noble" concept [Mączyńska 2011]. 
tomers' demographic, economic, geographical and psychosocial characteristics. It is also necessary to collect information about the above-mentioned customer expectations regarding the quality of goods and the prosocial activities that customers engage in. In consequence, the range of company market research increases and the information collected in the process of market research should be used for the purposes of a company's strategy.

The first CSR stage will mostly involve charity activities that can be random and sporadic and are seldom associated with a company's future financial results. As a result, companies do not analyse the effectiveness of CSR outlays and it is not necessary to introduce changes in the company's organisation of marketing. Companies most frequently increase the range of their promotional activities along with the frequency and intensity of the use of such promotional instruments as public relations and sponsoring. The subject literature also refers to such marketing activities as so-called cause-related marketing [Kozłowski 2008]. It is essentially restricted to promotional activities related to some particular social cause and charitable activities carried out by a company in order to solve a social problem. Potential customers are informed about the aims of such activities and the fact that a purchase of a company's product is linked to a particular social action. It has a positive impact on the image of the company as a socially responsible organisation sensitive to the needs of different communities. It makes the company recognisable on the market (brand awareness), helps to improve positioning of the company's products and as a result increases revenues and strengthens the company's competitive position.

If a company moves to subsequent CSR stages (strategic philanthropy), the range of such activities increases and is reflected in the company's marketing strategies. Activities of the CSR are then not of random but continuous and long-term character and are selected in accordance with certain defined criteria. Their aim is to enhance a company's competitiveness, addressing at the same time the socio-ecological needs of the company's environment. In consequence, the range of a company's marketing research is extended in order to address the CSR areas and to achieve a higher level of competitiveness. Marketing activi- ties generally focus on intensive promotion, including advertising, public relations and sponsoring. Companies use employee volunteering, engage customers and other stakeholders, launch social campaigns in cooperation with mass media and non-governmental organisations along with programs aimed to meet the expectations of the company's environment. At this stage companies also attempt to measure the effectiveness of CSR outlays. It is not necessary to introduce substantial changes in the company's marketing structure. Marketing activities supporting the CSR concept can be conducted by a company's marketing division operating on the basis of functional, product-related, geographical and market segment-oriented criteria depending on the specifics, offer and customers of a particular company.

Moving to the next CSR stage involves the use of the CSV concept that is creation of shared value. As at the previous stage, the company's marketing activities should start with marketing research that should collect information about the company's environment. It also refers to the foreign environment if the company operates or intends to operate abroad. Thus, the company should collect information about its potential customers, their characteristics and behaviours in the same way as at the previous stages of the CSR concept implementation. It is especially important, however, to extend the range of the company's marketing research incorporating into it the social areas corresponding to the company's profile and product offer. It is necessary to collect data about economic infrastructure, health care and education systems and the condition of the natural environment in the regions where the company operates or intends to operate. This data should be analysed in order to draw conclusions concerning potential problems in the above-mentioned areas of the company's environment. Therefore, it is necessary that the company should have a well-developed marketing information system. Then the company can juxtapose its resources and capacity with potential social problems in its environment. As a result, the company chooses the area in which it can start to create shared value, geographical markets in which it can operate and market segments. It may appear then that the company will have to deal with new markets and market segments. 
The next step is to define the company's marketing goals in the selected regions and with respect to the appropriate market segments. Selecting the area for creating shared value is in turn a basis to create the marketing tools, particularly those referring to production, technology and organization in the company. As far as the company's product policy is concerned, it is possible not to change the company's product offer and to use price-related and promotional instruments in CSV activities. The other option is to introduce changes to the company's product in order to create shared value. It should be supported by promotional activities and the use of pricing policies corresponding to the specifics of the selected market segment.

A further step concerning the company's product policy is to create a new product addressing the social needs of the company's environment. It can be a tangible product related to the company's existing product lines or a service provided by the company for the benefit of the community in a given region ${ }^{2}$. In relation to its product policy the company should also analyse the development of local clusters, including supply processes, production and provision of services. Its purpose is to launch new or improved products and to extend the company's group of suppliers in order to use raw materials and components offered by companies operating on the local markets on which the company's shared value will be created and offered.

It should be emphasised that it is extremely important that the company should have a marketing information system that will enable it to find local enterprises with the right potential which can participate in the company's supply chain and the process of creating shared value. A crucial element of CSV is the calculation of benefits resulting from the process of creating shared value. The company should make calculations of the costs incurred during the process of creating shared value and the sales revenues by taking into account different variants. The next step can be defining other marketing activities and tools connected with distribution and promotion and closely associated with the shared value. The company can change or extend its distribution channels by incorporating companies from the markets on which it operates. It is especially the case when creating shared value involves entering new geographical markets. The potential of local companies can be also used in activities promoting the created shared value. Implementing the CSV concept does not have to cause essential changes in the organizational structure of marketing. It can involve, however, expand the marketing research division which collects data about the company's environment, looks for new markets and local clusters on new markets.

The use of the CSV concept is also related to the type of marketing strategy. This is especially visible in the case of strategies distinguished by the market on which the company operates and its product offer (the so-called Ansoff matrix). Ansoff has defined four development strategies here: market penetration, market development, product development and diversification (innovation).

- The market penetration strategy assumes no changes in the product offer and the use of other marketing-mix instruments for a company's development and sales growth. The company aims at increasing the frequency of purchases by the buyers, increasing the number of purchases, and limiting the purchases of competitive products by consumers. These goals can be achieved by offering new after-sales services, using new distribution channels, intensive promotional activities, price reductions.

- The market development strategy consists in introducing existing products to new markets. This objective can be achieved by taking over market segments serviced so far by competitors or offering products to buyers (new segments) who have not yet purchased a given product. There is also a possibility of geographical expansion, i.e. entering new territorial markets - e.g. foreign markets.

- The product development strategy assumes offering modified or new products on existing markets. Modification can take place by improving the

\footnotetext{
${ }^{2}$ An example of creating shared value can be organising and financing language courses and training for school-age youth in regions with low household incomes by a manufacturer of computer and audio-visual equipment. It will improve the level of education in the region, young people's chances for further education and getting a job. At the same time, it improves the company's image and increases sales opportunities.
} 
quality of products, adding new additional functions, changes in colour, packaging, size, varieties and new product models. Similar activities are used in relation to other marketing-mix tools, and this particularly applies to promotion.

- The diversification (innovation) strategy is to introduce new products to new markets. This can be achieved by offering new products to new segments of buyers or by offering new products on new territorial markets, e.g. abroad. The company must therefore create a new product on its own, buy a license or patent for the new product or absorb a producer who has the new product at its disposal [Grzegorczyk 2015]. It also happens that the company, in order to create its own new product faster, buys suppliers of raw materials, materials, intermediate products or subcontractors (vertical diversification).

From the above-mentioned types of marketing strategies, the CSV concept can be applied to product development and diversification strategies. In the first instance, new products are created, which can be of common value or can be created through cooperation with local companies and the development of local clusters, including the supply of raw materials, production or new product distribution systems in existing markets. With regard to the strategy of diversification (innovation), the selection of new markets should include an examination of their social and environmental problems, the needs of buyers and the market structure of suppliers and intermediaries. This provides a basis for creating new products that take these needs into account, and helps create local supply and production clusters to enter new markets.

As has been emphasised above, CSR implementation requires, among other things, building long-term partner relationships with groups of stakeholders, particularly with a company's customers, regardless of what stage the CSR process in the company is at Therefore, it is necessary that a company follow the principles of partnership marketing (also called relationship marketing). The definitions of relationship marketing emphasise the importance of relationships for a company's market strategy, to quote just two examples: Relationship marketing is, among others, used to transform the company's customers into co-creators of the company's product or value in order to connect them with the company on a long-term basis [Rogoziński 1998]. The idea of relationship marketing involves creating and maintaining bilateral and multilateral relationships with the company's customers and other subjects in the process of creating and supplying goods and services [Fonfara 1999].

As can be seen, the main purpose of relationship marketing is to strive to build long-lasting and satisfying relationships with stakeholders which contribute to the increase of social welfare. According to the CSR concept, this relationship building involves not only customers but also suppliers, intermediaries, potential employees and the so-called influential institutions (e.g. banks, insurance sector, consumer associations, social movements, environmental protection institutions). It has been noted above that in consequence of these assumptions a company widens the scope of its marketing research by collecting more detailed information about stakeholder behaviours and relationships. The tools that companies use in their marketing strategies in practice are customer relationship management (CRM) programmes. Customer relationship management is based on the information systems available and regularly monitors the behaviours, needs and expectations of customers in order to build and maintain long-term relationships with them.

\section{SUMMARY}

The CSR concept is closely related to a company's marketing strategy. Its assumptions are part of a company's mission, which, in turn, determines a company's marketing strategy. The last stage of CSR implies that the importance of a company's marketing research increases and that the organisational unit dealing with it should be expanded. The links between CSV and a company's marketing strategy can be especially noticed in the process of assessing and selecting new markets and new market segments. They also concern changes in product policy that should involve creating products representing shared value. These links also refer to a company's distribution policy which should include creating local clusters and engaging local companies into the process of production and distribution. 


\section{REFERENCES}

Błach, J., Gorczyńska, M., Wieczorek-Kosmala, M. (2017). Perspektywa CSR a cel działania przedsiębiorstw - studium na przykładzie wybranych spółek. Annnales Universitatis Marie Curie Skłodowska, Lublin. Oeconomia, 51 (4), 25-35.

Buczkowski, B., Dorożyński, T., Kuna-Marszałek, A., Serwach, T., Wieloch, J. (2016). Społeczna odpowiedzialność biznesu. Studium przypadków firm międzynarodowych. Wydawnictwo Uniwersytetu Łódzkiego, Łódź.

Czubała, A. (2013). Koncepcja i formy marketingu społecznego przedsiębiorstw. Zeszyty Naukowe Małopolskiej Wyższej Szkoły Ekonomicznej w Tarnowie, 22 (1), $25-34$.

Fonfara, K. (1999). Marketing partnerski na rynku. PWE, Warszawa.

Grzegorczyk, W. (2015). Marketing na rynku międzynarodowym. Wolters Kluwer, Warszawa.

Janeczek, U. (2014). Koncepcja społecznej odpowiedzialności biznesu a marketing relacji. Studia Ekonomiczne. Uniwersytet Ekonomiczny w Katowicach, 182, 30-41.

Kozłowski, W. (2008). Cause-related marketing w badaniach naukowych w praktyce biznesowej. Marketing i Rynek, 6, 9-14.

Krzepicka, A.K., Tarapata, J. (2013). Strategia CSR, czyli tworzenie wspólnej wartości. Prace Naukowe Uniwersytetu Ekonomicznego we Wrocławiu, 288, 84-94.
Mączyńska, E. (2011). Miary finansów przedsiębiorstwa i ich adekwatność. Prace Naukowe Uniwersytetu Ekonomicznego we Wrocławiu, 172, 388-402.

Mirvis, P., Goggins, B. (2006). Stages of Corporate Citizenship. California Management Review, 48 (2), 104-126.

Porter, M.E., Kramer, M.R. (2011). Creating Shared Value. How to reinvent capitalism and unleash a wave of innovation and growth. Harvard Business Review, 89 (1-2), 62-77.

Rogoziński, K. (1998). Nowy marketing usług. Wydawnictwo Uniwersytetu Ekonomicznego w Poznaniu, Poznań.

Urbanowska-Sojkin, E., Weinert, A., (2016). Rozwój koncepcji CSV na kanwie krytyki społecznej odpowiedzialności biznesu. Przegląd Organizacji, 6, 31-36.

Visser, W. (2012). The Future of CSR: Towards Transformative CSR, or CSR 2.0. Kaleidoscope Futures Paper Series, 1, http://doi.org/10.2139/ssrn.2208101

Witek-Crabb, A. (2016). Ewolucyjne modele CSR - przegląd koncepcji społecznej odpowiedzialności biznesu. Prace Naukowe Uniwersytetu Ekonomicznego we Wrocławiu, 444, 541-558.

Żychlewicz, M. (2015). Społeczna odpowiedzialność biznesu jako strategia prowadzenia działalności polskich przedsiębiorstw. Zeszyty Naukowe Uniwersytetu Szczecińskiego, 858. Współczesne Problemy Ekonomiczne, 11, 281-289.

\section{RELACJE MIĘDZY KONCEPCJĄ CREATING SHARED VALUE A STRATEGIĄ MARKETINGOWĄ PRZEDSIĘBIORSTWA}

\section{STRESZCZENIE}

Celem publikacji jest próba określenia relacji między koncepcjami corporate social responsibility (CSR) oraz creating shared value (CSV) a strategią marketingową. Dla realizacji tego celu wykorzystano metodę krytycznej analizy literatury krajowej i zagranicznej odnoszącej się do tych zagadnień. Na tej podstawie sformułowano wnioski określające zakres i treści tych relacji. Odnoszą się one przede wszystkim do misji przedsiębiorstwa, prowadzonych przez nie badań marketingowych i strategii marketingowej. Współzależność CSV i strategii marketingowej można szczególnie dostrzec w ocenie i wyborze nowych rynków geograficznych i nowych segmentów nabywców. Odnoszą się one do zmian polityki produktu - kreowania produktów stanowiących wspólną wartość. Relacje dotyczą także polityki dystrybucji, która może dotyczyć tworzenia lokalnych klastrów i włączania do produkcji i dystrybucji firm z tych rynków.

Słowa kluczowe: CSR, CSV, strategia marketingowa 